\title{
Advancing Health Equity During the COVID-19 Pandemic through Digital Medical Interpretation Platforms
}

Nazia Sharfuddin ( $\nabla$ sharfudd@ualberta.ca )

University of Alberta https://orcid.org/0000-0002-2563-9674

Pamela Mathura

University of Alberta

Emily Ling

University of Alberta

Ellen Bruseker

Alberta Health Services

Areej Rajeh

University of Alberta

Jennifer Woods

Alberta Health Services

Yvonne Suranyi

Alberta Health Services

Narmin Kassam

University of Alberta

\section{Research article}

Keywords: Medical Interpretation Services (MIS), Health Equity, COVID-19, limited English proficiency (LEP), Emergency Department (ED)

Posted Date: April 5th, 2021

DOI: https://doi.org/10.21203/rs.3.rs-384431/v1

License: (c) (i) This work is licensed under a Creative Commons Attribution 4.0 International License.

Read Full License 


\begin{abstract}
:
Background: Medical Interpretation Services (MIS) is the gold-standard that should be used during clinical assessments with patients who have limited English proficiency (LEP) or have hearing loss. The COVID-19 pandemic has highlighted the urgent need for clear, concise medical communication between patients and clinicians to prevent the spread of COVID-19 and ensure public safety. Cost of MIS is covered by the provincial health authority in <Blinded $>$; however, it is not consistently utilized across the province.
\end{abstract}

Aim: To implement digital MIS in the Emergency Department (ED) of one urban teaching hospital, improving accuracy of clinical assessment and to provide patient-centered communication.

Methods: Applying quality improvement methodology, an intervention comprised of digital MIS technology and education was trialed for 6 months. To assess intervention effect, the number of MIS minutes and calls were measured monthly and a questionnaire was developed and administered to determine ED healthcare providers' awareness, technology accessibility and perception of MIS integration into the clinical workflow.

Results: Digital MIS was utilized consistently in the ED from the beginning of the COVID-19 pandemic (March 2020) and over the subsequent six months. The cost avoidance due to digital MIS usage was estimated to be $\$ 19,612.16$. ED healthcare providers indicated that digital MIS helped smooth communication with patients and reduced the time it took to gather and provide accurate information.

Conclusion: Providing digital MIS access, education and training is a means to advance health equity, by improving accuracy of clinical assessment and patient-centered care in the ED. 


\section{BACKGROUND}

Inaccurate communication with patients leads to gaps in patient assessment and care, and further contributes to disparities in health care access and delivery, representing inequitable care as a result of system design ${ }^{1,2,3,4}$. The COVID-19 pandemic has highlighted the urgent need for clear, concise medical communication between patients and clinicians to prevent the spread of COVID-19 and ensure public safety. Without access to services that appropriately support communication, patients who have limited-English proficiency (LEP) are inherently disadvantaged when navigating the healthcare system. Absence of clear and effective communication with patients leads to increased risks of medical errors, longer hospital stays and higher readmission rates ${ }^{1,3}$. This further contributes to reduced patient care and satisfaction overall $^{1,3,5}$. In Canada, nearly 4 million people (11.5\%) speak a non-English or French language at home and 650,000 (1.9\%) do not speak either English or French ${ }^{6}$. Across Canada, many centres have various Medical Interpretation Services (MIS) available ranging from in-person, remote telephone or remote video services. However, these tools are not universally employed when interacting or assessing patients with language barriers. Instead, ad hoc interpreters such as family, friends and untrained (in MIS) clinical staff are often utilized. Consequences of this include incorrect medication dosing and inaccurate patient histories ${ }^{7,8}$. In contrast, utilizing professional MIS increases patient understanding of their disease processes and adherence to management plans $^{2,3}$. Moreover, it improves LEP patient care and clinical outcomes to a level that closely matches clinician-patient interactions without communication gaps ${ }^{3,5}$

In <Blinded $>$, MIS is funded by the provincial health authority, <Blinded $>$ Health Services (XHS), for any publicly funded care setting across the 5 health zones in the province ${ }^{9}$. Services provided include in-person interpretation (IPI), phone remote interpretation (PRI) and video remote interpretation (VRI) that are approximately quoted at $\$ 136 /$ hour, $\$ 0.86 /$ minute and $\$ 1.55 /$ minute, respectively ${ }^{9}$. Between 2011 and 2016, the number of people in $\langle$ Blinded $\rangle$ who did not converse in English or French increased by $19.7 \%{ }^{10}$. However, a proportionate increase in MIS usage was not observed. IPI is costly and neither PRI nor VRI are commonly used or accessible within the <Blinded $>$ Zone. We identified that one urban, quaternary teaching hospital Emergency Department (ED) had the lowest utilization of MIS across the <Blinded> Zone and did not have access to VRI. Moreover, the COVID-19 pandemic resulted in the ban of in-person MIS.

We aimed to increase digital MIS utilization in the ED, through increased accessibility and awareness, in order to improve accuracy of communication and patient-centered care for LEP and hearing-impaired patients, to bridge healthcare delivery disparities during COVID-19 pandemic and beyond.

\section{METHODS}

\section{Study Design}

The Model of Improvement provided the framework to guide our study ${ }^{11}$. The key components were the development of a study team, quality improvement (QI) tool completion (process mapping and Ishikawa diagram), focused aim determination, intervention adaptation and evaluation with iterative plan do study act (PDSA) cycles. Our study team comprised of the 
clinical lead for the <Blinded $>$ Zone, a resident physician, medical and nursing students, provincial program lead for MIS, QI specialist, executive director and patient care manager of the ED. We completed the XRECCI (X pRoject Ethics Community Consensus Initiative) screening tool ${ }^{12}$ that classified this study as QI with minimal risk to participants which did not require full ethics board review as per local organizational policies.

\section{Study Setting}

Our study took place in one ED within the <Blinded $>$ Zone. To determine baseline ED MIS usage prior to the start of this study was not possible as usage was tracked for the entire hospital, not for specific departments. However, initial consultation with ED healthcare workers revealed a very low level of awareness around the cost, accessibility and evidence-based recommendations supporting remote MIS platforms. Additionally, MIS was perceived as a disruption to workflow, where ED staff historically relied on IPI or ad hoc modes of interpretation. There was no VRI available in the ED prior to our study. This left IPI as the only MIS option available for hearing-impaired patients.

\section{Intervention}

We introduced digital MIS technology coupled with education and training to facilitate adoption on the third week of March 2020 following the global declaration of the COVID-19 pandemic. The technology was described as an "Interpreter-on-Wheels" (IOW) which comprised of a tablet attached to an IV pole for portability (Figure 1). The tablet hosts the MIS application on its home screen featuring both VRI and PRI options. Education on the evidence behind MIS, appropriate use of the technology, trouble shooting, cleaning and storage was provided by the MIS program lead. Targeted sessions with ED staff were held during morning huddles, at shift change and one to one as appropriate.

\section{Measures}

The Donabedian conceptual evaluation model was used to determine our measurement approach $^{13}$. The outcome measure was the monthly number of digital MIS (VRI and PRI) calls and minutes within the ED. A unique code was assigned to all calls made on the IOW to facilitate tracking ED MIS usage. The process measures were the number of IOWs available and level of MIS awareness. The balancing measures were the length of time taken to communicate with the patient and the ease of MIS integration into the ED workflow.

\section{Data Collection and Analysis}

Monthly MIS usage data was gathered by the Interpretation \& Translation Services department and was provided to our study team for analysis. We used this data to determine the percentage of ED usage compared to the rest of the hospital and to estimate cost avoidance related to inperson interpretation, which was the most used interpretation modality in this ED before the COVID-19 pandemic. Further, to understand the ED healthcare providers' perspectives, we developed a brief voluntary questionnaire. The initial paper-based questionnaire was piloted with the ED patient care manager, a nurse and a resident. Modifications were made to the wording of questions and answer options which then resulted in the final questionnaire, which was administered six months after the intervention started. Written consent was obtained from participants prior to completion and provider occupation was collected. No personal identifiable information was collected. The questionnaire sought to understand the need for MIS, awareness, 
access, ease of use of digital MIS, workflow integration, and perception of patient care delivery related to using digital MIS and further areas for improvement. Questionnaire dissemination and data analysis was completed over one week in Oct 2020. Aiding data analysis, the completed questionnaire responses were inputted into Google Form which generated descriptive statistics.

\section{RESULTS}

Digital MIS usage data was tracked by the number of minutes and calls per modality (VRI or PRI) per month, over a six-month period (Table 1). During the intervention timeframe (March to September, 2020), digital MIS usage in the ED represented approximately $37.5 \%$ of total hospital usage. Decreased usage in June and July coincided with overall decreased visits to the ED during these months. Average call duration was 12.3 (VRI) and 14.6 minutes (PRI). PRI was utilized more than VRI. The top 10 languages encountered were: Arabic (20\%), Swahili (11\%), Tigrinya (9\%), Somali (8\%), Cantonese (7\%), Dari (7\%), French (6\%), Spanish (5\%), American Sign Language (4\%) and Oromo (4\%). These languages reflect some of the top non-official languages spoken by patients in $\langle$ Blinded $>$.

Prior to our intervention, there was no VRI option available. Thus, any VRI usage can be directly linked to the introduction of the VRI option on the IOW. Furthermore, PRI usage historically was very low; therefore, it can be extrapolated that increase in PRI usage was related to the education strategies and access to IOW.

After implementing the IOW, we collected 105 questionnaires from ED staff to assess MIS awareness and user experience. Most respondents were nurses (71.2\%) and staff who worked a day shift (63.8\%). The majority (83.8\%) of staff had some familiarity with the various MIS platforms available and regularly encountered situations that required MIS. IPI was the preferred interpretation modality (87.5\%) followed by PRI (53.8\%) and VRI (34.29\%). Additionally, most were aware of the new IOW in the ED $(73.1 \%)$ and believed that digital MIS provided better patient care $(76.7 \%)$. Although setting up the IOW took time, participants found that digital MIS helped smooth communication with patients and reduced the time it took to gather and provide accurate information. Respondents suggested that providing further training on how to use the IOW, increasing the number of devices and having a designated IOW storage location in the ED would increase awareness and accessibility.

To calculate cost avoidance due to digital MIS use, we compared the total cost incurred during our intervention period to the hourly costs of IPI. There was a total of 1,789 PRI minutes and 806 VRI minutes at a cost of $\$ 1,538.54$ and $\$ 1,249.30$ respectively. The total cost of digital MIS was $\$ 2,787.84$ compared to an equivalent IPI cost of $\$ 22,400$. This represents a total cost-avoidance of $\$ 19,612.16$.

\section{DISCUSSION}

Effective communication between patients and physicians is an important determinant of the quality of care patients receive as well as their overall experience within the healthcare system. Language barriers can directly contribute to patient misunderstanding regarding their diagnosis and management plan which may compromise their personal safety and health outcomes ${ }^{7.14}$. LEP 
patients are at higher risks for medical errors and adverse hospital events, and generally report lower patient satisfaction ${ }^{1,3,5,7}$. Furthermore, ad hoc interpretation is associated with poor patient outcomes similar to no interpretation at all, and can raise confidentiality and ethical concerns $^{1,7,15}$. Untrained interpreters may lack suitable health literacy in a second language, leaving potential for gaps in care and communication. Thus, it is crucial that MIS are utilized to bridge this communication gap and reduce the healthcare disparities that LEP patients face. Digital MIS makes that capability more pronounced.

We utilized QI methodology to implement digital MIS to improve care for LEP and hearingimpaired patients, which demonstrated multiple benefits: ease of use, affordability, and flexibility. Digital MIS provided significant cost-avoidance. It is available on-demand for 240 languages providing increased flexibility compared to IPI or ad hoc interpretation. Furthermore, while digital MIS is commonly criticized for being disruptive to workflow ${ }^{15,16,17}$, most healthcare workers in our study found that using digital MIS led to more efficient patient assessments and delivery of care. The average length of PRI and VRI encounters were relatively short (14.6 and 12.3 minutes, respectively), dispelling the myth that digital MIS leads to lengthy patient encounters. Moreover, the ED staff reported high satisfaction with the digital MIS platforms and desired further training to enhance their comfort in using the tool.

Based on the ED healthcare providers' post-intervention questionnaire recommendations, we added two IOW devices for the ED triage and the pediatric ED. We also posted additional signage in the ED to increase healthcare providers' awareness and understanding of the different MIS modalities (Figure 2). To improve patient awareness of MIS as a clinical service option, signage in the top ten local languages was posted near triage and admission areas (Figure 3 ). In addition, we have increased MIS PRI accessibility by pre-programming ED phones with a speeddial feature and have applied stickers to ED phones that contain PRI telephone number for quick reference. In the next 3 months, we will be providing additional training and education and we are also planning to collect patient digital MIS experience data. We will continue to undertake regular questionnaires on an annual basis to assess impact, ease of adoption, barriers to use, gaps in knowledge or training, and other feedback in order to continuously improve and sustain MIS.

\section{LIMITATIONS}

The COVID-19 pandemic led to the termination of IPI which may have inflated the usage of digital MIS in the ED. Further, the lack of ED-specific MIS usage minutes prior to the intervention prevented accurate pre and post intervention comparison. Even though our study created a unique code for tracking MIS usage through the IOW in the ED, staff could access PRI through hospital or personal telephones using a generic code not linked to the ED. Therefore, there may be an under-estimate of the actual ED MIS usage data.

\section{CONCLUSION}

The COVID-19 pandemic has highlighted the critical role of accurate communication in delivering timely and accessible care alongside improving reach of public health and safety information. Effective communication between patients and physicians is an important determinant of the quality-of-care patients receive as well as their overall experience within the healthcare system. By utilizing MIS via remote digital platforms, there is a significant potential 
to bridge disparities in healthcare delivery and outcomes. We strive to utilize our quality improvement project to establish a sustainable, affordable and streamlined approach to using digital MIS for LEP and patients with hearing loss, thus improving clinical assessments and patient-centered experiences in the ED.

\section{ABBREVIATIONS}

- ED: Emergency Department

- IOW: Interpreter-On-Wheels

- IPI: In-Person Interpretation

- LEP: Limited English proficiency

- MIS: Medical Interpretation Services

- PRI: Phone Remote Interpretation

- QI: Quality Improvement

- VRI: Video Remote Interpretation 
Table 1

Monthly Emergency Department Digital MIS Usage

\begin{tabular}{|l|l|l|l|l|l|l|l|}
\hline & Mar* & Apr & May & Jun & Jul & Aug & Sep \\
\hline $\begin{array}{l}\text { Video } \\
\text { Minutes on } \\
\text { IOW }\end{array}$ & 35 & 216 & 134 & 75 & 99 & 137 & 110 \\
\hline $\begin{array}{l}\text { Phone } \\
\text { Minutes on } \\
\text { IOW }\end{array}$ & 0 & 521 & 364 & 43 & 80 & 386 & 395 \\
\hline $\begin{array}{l}\text { Number of } \\
\text { PRI calls in } \\
\text { ED }\end{array}$ & 0 & 48 & 31 & 7 & 6 & 32 & 35 \\
\hline $\begin{array}{l}\text { Number of } \\
\text { VRI calls in } \\
\text { ED }\end{array}$ & 6 & 13 & 11 & 5 & 8 & 11 & 11 \\
\hline $\begin{array}{l}\text { ED } \\
\text { proportion of } \\
\text { Total } \\
\text { Hospital- } \\
\text { Wide MIS }\end{array}$ & $4.88 \%$ & $37.65 \%$ & $17.57 \%$ & $10.71 \%$ & $10.94 \%$ & $24.86 \%$ & $25.27 \%$ \\
\hline $\begin{array}{l}\text { ED } \\
\text { proportion of } \\
\text { Total } \\
\begin{array}{l}\text { Hospital- } \\
\text { Wide MIS } \\
\text { Minutes (VRI } \\
+ \text { PRI) }\end{array}\end{array}$ & $2.04 \%$ & $32.76 \%$ & $15.76 \%$ & $6.87 \%$ & $8.55 \%$ & $17.38 \%$ & $21.24 \%$ \\
\hline
\end{tabular}

*The IOW was introduced to the ED on March 25, 2020. Therefore, this table captures only 7 days' worth of usage in March 2020. 


\section{DECALARATIONS}

Ethics Approval \& Consent to Participate: All participants who responded to the survey provided written consent to participate. We completed the ARECCI (Alberta pRoject Ethics Community Consensus Initiative) screening tool ${ }^{18}$ that classified this study as Quality Improvement with minimal risk to participants which did not require full ethics board review as per local organizational policies.

Consent to Publish: All participants who responded to the survey provided consent for publication. All members involved in the project from methodology design, data collection, analysis, and manuscript authorship also provided consent for publication.

Availability of Data and Materials: All data available via <Blinded > Health Services Interpretation Services department. The datasets used and/or analysed during the current study available from the corresponding author on reasonable request.

\section{Competing Interests: none}

Funding: not applicable. The cost of digital medical interpretation services is funded by the provincial health authority, <Blinded $>$ Health Services. No additional funding was procured for our project.

Authors' Contributions: Each of the authors confirms that this manuscript has not been previously published and is not currently under consideration by any other journal. Additionally, all the authors have approved the contents of this paper and have agreed to the BMC Health Services Research submission policies. NS and PM were responsible for conception and design of study, led acquisition of data, analysis and drafting the manuscript. EL co-led drafting the manuscript; EB and AR conducted the statistical data analysis and interpretation; JW, YS and NK were responsible for revising the manuscript critically for important intellectual content. All authors provided approval of the version of the manuscript to be published. Additionally, to the best of our knowledge, the named authors have no conflict of interest, financial or otherwise.

\section{Acknowledgements:}

We would like to thank the University of <Blinded $>$ Hospital and <Blinded $>$ Health Services Interpretation \& Translation Services.

This study was presented as part of a quality improvement poster at the virtual <Blinded> Internal Medicine Conference November 19-20, 2020. 


\section{REFERENCES:}

${ }^{1}$ Juckett G, Unger K. Appropriate use of medical interpreters. Am Fam Physician. 2014;90(7):476-480.

2 Jacobs EA, Lauderdale DS, Meltzer D, Shorey JM, Levinson W, Thisted RA. Impact of interpreter services on delivery of health care to limited-English-proficient patients. J Gen Intern Med. 2001;16(7):468-474. doi:10.1046/j.1525-1497.2001.016007468.x

${ }^{3}$ Karliner, Leah $\mathrm{S}$ et al. "Do professional interpreters improve clinical care for patients with limited English proficiency? A systematic review of the literature." Health services research vol. 42,2 (2007): 727-54. doi:10.1111/j.1475-6773.2006. 00629.x

${ }^{4}$ Steinburg, E., Valenzuala-Araujo, D., Zickafoose, J., Keiffer, E., \& DeCamp, L. (2016). The "battle" of managing language barriers in health care. Clinical Pediatrics, 5(14), 1318-1327.

${ }^{5}$ Kasten, Mary J., et al. "INTERPRETERS IN HEALTHCARE: A CONCISE REVIEW for Clinicians." The American Journal of Medicine (2020).

${ }^{6}$ Statistics Canada. 2017. Canada [Country] and Canada [Country] (table). Census Profile. 2016 Census. Statistics Canada Catalogue no. 98-316-X2016001. Ottawa. Released November 29, 2017.

${ }^{7}$ Flores G, Abreu M, Barone CP, Bachur R, Lin H. Errors of medical interpretation and their potential clinical consequences: a comparison of professional versus ad hoc versus no interpreters. Ann Emerg Med. 2012;60(5):545-553. doi:10.1016/j.annemergmed.2012.01.025

${ }^{8}$ van Rosse F, de Bruijne M, Suurmond J, Essink-Bot ML, Wagner C. Language barriers and patient safety risks in hospital care. A mixed methods study. Int J Nurs Stud. 2016;54:45-53. doi:10.1016/j.ijnurstu.2015.03.012

${ }_{9}^{9}<$ Blinded $>$ Health Services. (n.d.). Interpretation \& Translation Services. Retrieved April 1, 2020, from https://www. $<$ Blinded $>$ healthservices.ca/findhealth/Service.aspx?id=1080491

${ }^{10} 2016$ Census of Canada, Language Characteristics of $<$ Blinded $>$ ns.

${ }^{11}$ Langley, G., Moen, R., Nolan, K., Nolan, T., Norman, C., \& Provost, L. (2009). The Improvement Guide. John Wiley \& Sons.

${ }^{12}$ Hagen B, O'Beirne M, Desai S, Stingl M, Pachnowski CA, Hayward S. Innovations in the Ethical Review of Health-Related Quality Improvement and Research: The <Blinded> Research Ethics Community Consensus Initiative (ARECCI). Healthc Policy 2007;2(4):e164-77.

${ }^{13}$ Donabedian, A. (2005) Evaluating the quality of medical care. The Milbank Quarterly, 83(4):691-729. https://doi.org/10.1111/j.1468-0009.2005.00397.x 
${ }^{14}$ van Rosse F, de Bruijne M, Suurmond J, Essink-Bot ML, Wagner C. Language barriers and patient safety risks in hospital care. A mixed methods study. Int J Nurs Stud. 2016;54:45-53. doi:10.1016/j.ijnurstu.2015.03.012

${ }^{15}$ Hsieh E. Not just "getting by": factors influencing providers' choice of interpreters. J Gen Intern Med. 2015;30(1):75-82. doi:10.1007/s11606-014-3066-8

${ }^{16}$ Rocque, R. \& Leanza, Y. (2015). A systematic review of patients' experiences in communicating with primary care physicians: Intercultural encounters and a balance between vulnerability and integrity. PLOS One, 10(10), 1-32.

${ }^{17}$ Rayburn. (2017). Lost in translating: Current issues with medical interpreting in pediatric nursing. Pediatric nursing, 43(5), 247-249.

${ }^{18}$ Hagen B, O'Beirne M, Desai S, Stingl M, Pachnowski CA, Hayward S. Innovations in the Ethical Review of Health-Related Quality Improvement and Research: The <Blinded > Research Ethics Community Consensus Initiative (<X>RECCI). Health Policy 2007;2(4):e164-77. 


\section{Figures Legend}

\section{Figure 1}

Interpreter on Wheels: it includes the digital MIS application displayed on the home screen of a tablet attached to an IV pole.

\section{Figure 2}

MIS usage poster showcasing the digital platforms, comprising of phone \& video modalities, compared to in-person interpretation

\section{Figure 3}

Patient information poster showcasing top 20 languages in <Blinded $\rangle$ with the same message "Point to Your Language for Interpreters" 
Figure 1

Interpreter on Wheels: it includes the digital MIS application displayed on the home screen of a tablet attached to an IV pole.

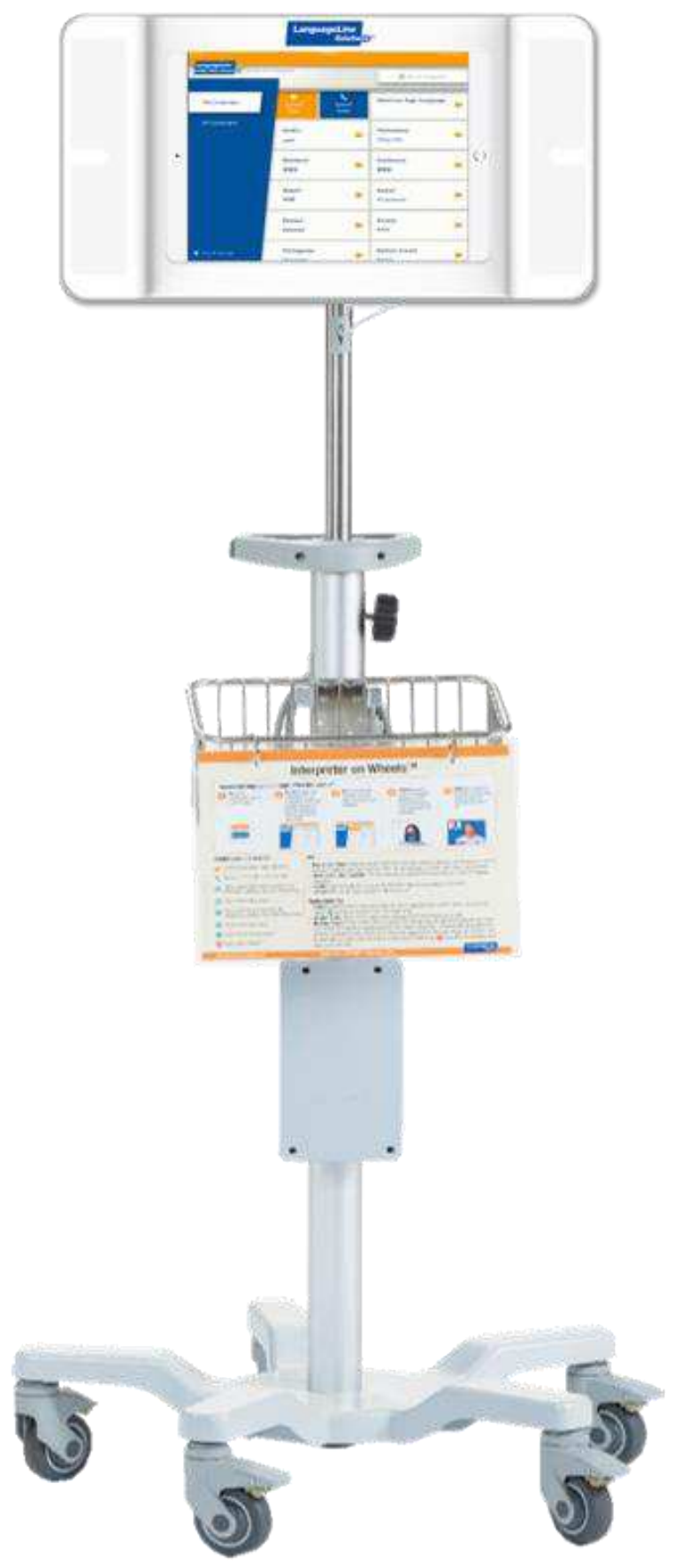




\section{Figure 2}

MIS usage poster showcasing the digital platforms, comprising of phone \& video modalities, compared to in-person interpretation

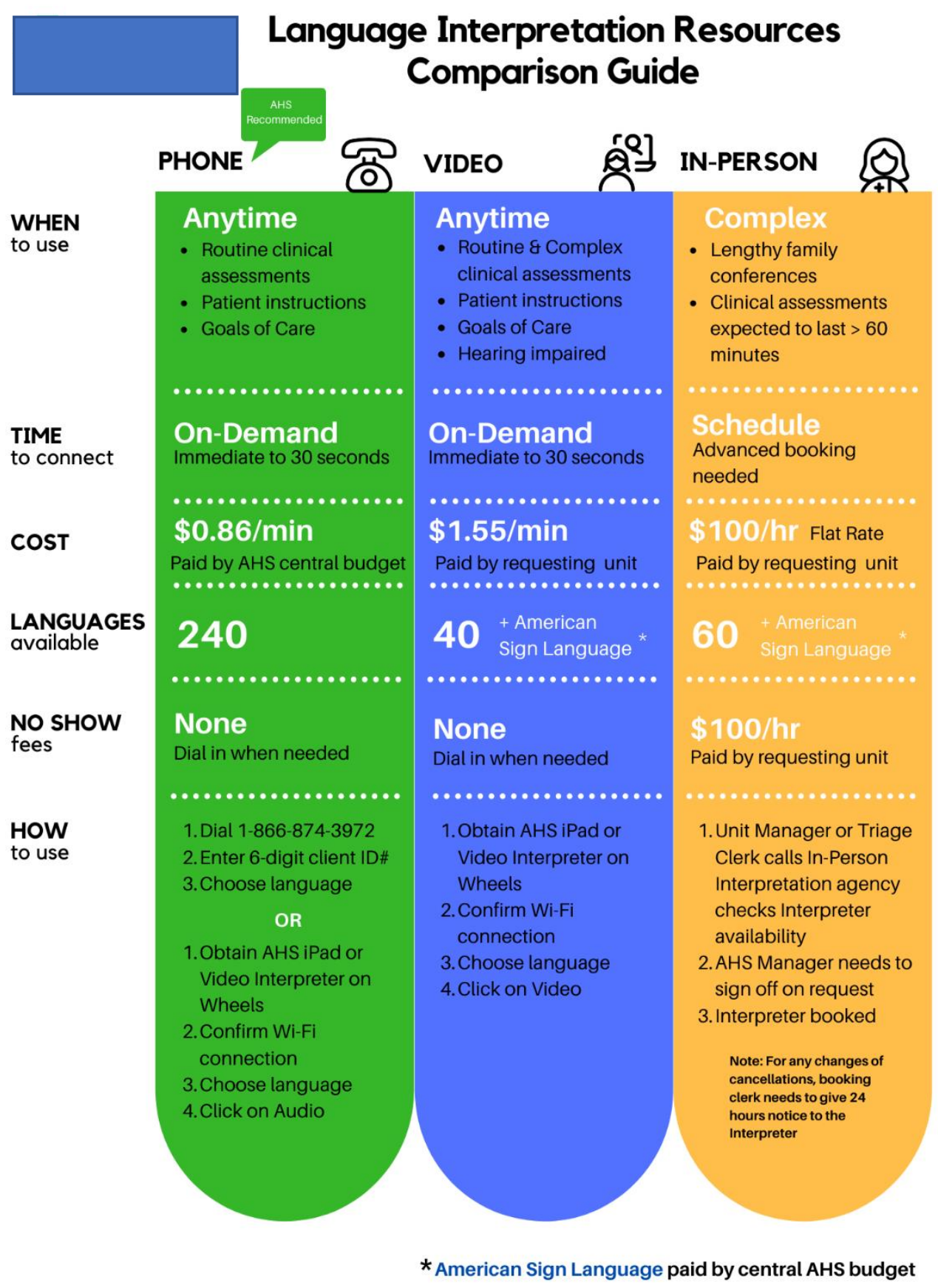


Figure 3

Patient information poster showcasing top 20 languages in <Blinded > with the same message "Point to Your Language for Interpreters"

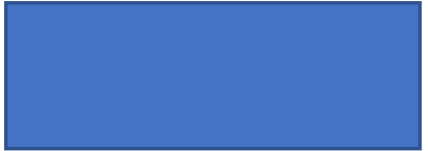

Interpretation \&

Translation Services

English Translation: Point to your language. An interpreter will be called. The interpreter is provided at no cost to you.

\begin{tabular}{|c|c|}
\hline $\begin{array}{l}\text { American Sign Language } \\
\text { Point to your language. An interpreter will be called. } \\
\text { The interpreter is provided at no cost to you. }\end{array}$ & $\begin{array}{ll}\text { Oromo } & \text { Oromo } \\
\text { Gara afaan keetti eeri. Turjumaanni ni waamama. } & \\
\text { Turjumaanni beesee takka malee sif qophaawa. } & \end{array}$ \\
\hline 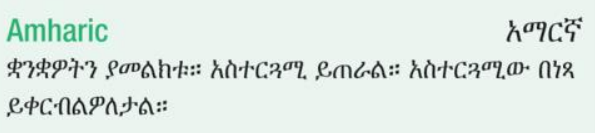 & 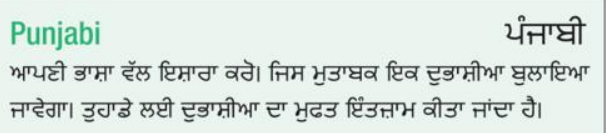 \\
\hline 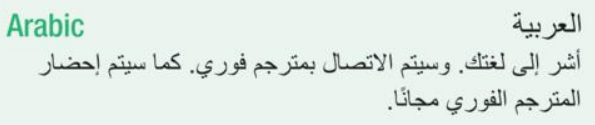 & $\begin{array}{l}\text { Russian Русский } \\
\text { Укажите язык, на котором вы говорите. Вам вызовут } \\
\text { переводчика. Услуги переводчика предоставляются бесплатно. }\end{array}$ \\
\hline $\begin{array}{l}\text { Cantonese } \\
\text { 請指認您的語言, 以便為您提供免費 } \\
\text { 的口譯服務。 }\end{array}$ & $\begin{array}{l}\text { Somali Af-Soomaali } \\
\text { Farta ku fiiqluqadaada... Waxa laguugu yeeri doonaa turjubaan. } \\
\text { Turjubaanka wax lacagi kaaga bixi mayso. }\end{array}$ \\
\hline 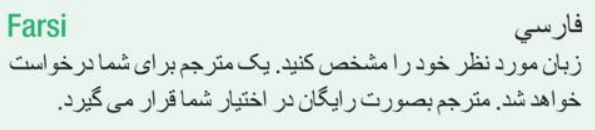 & $\begin{array}{l}\text { Spanish Español } \\
\text { Señale su idioma y llamaremos a un intérprete. El servicio } \\
\text { es gratuito. }\end{array}$ \\
\hline $\begin{array}{l}\text { French Français } \\
\text { Indiquez votre langue et nous appellerons un interprète. } \\
\text { Le service est gratuit. }\end{array}$ & $\begin{array}{l}\text { Swahili } \\
\text { Onyesha lugha yako. Mkalimani ataitwa. Utapewa } \\
\text { mkalimani bila gharama yoyote. }\end{array}$ \\
\hline $\begin{array}{l}\text { हिंदी } \\
\text { अपनी भाषा को इंगित करें। जिसके अनुसार आपके लिए दुभाषिया बुलाया } \\
\text { जाएगा। आपके लिए दुभाषिया की निशुल्क व्यवस्था की जाती है। }\end{array}$ & $\begin{array}{l}\text { Tagalog Tagalog } \\
\text { Ituro po ang inyong wika. Isang tagasalin ang ipagkakaloob } \\
\text { nang libre sa inyo. }\end{array}$ \\
\hline $\begin{array}{l}\text { Korean 한국어 } \\
\text { 귀하께서 사용하는 언어를 지정하시면 해당 언어 } \\
\text { 통역 서비스를 무료로 제공해 드립니다. }\end{array}$ & 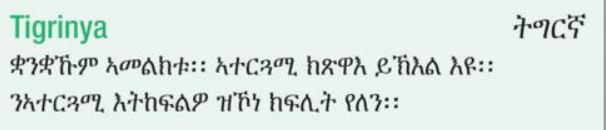 \\
\hline $\begin{array}{l}\text { Mandarin } \\
\text { 请指认您的语言, 以便为您提供免费 } \\
\text { 的口译服务。 }\end{array}$ & 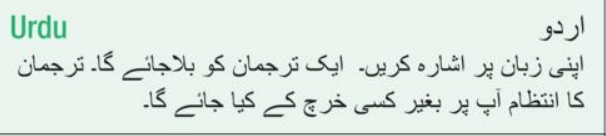 \\
\hline $\begin{array}{l}\text { नेपाली } \\
\text { आफ्नो भाषातर्फ औल्याउनुहोस्। एक दोभाषेलाई बोलाइनेछ। } \\
\text { तपाईंको कुनै खर्च बिना, एकजना दोभाषे उपलब्ध गराइनेछ। }\end{array}$ & $\begin{array}{l}\text { Vietnamese Tiếng Việt } \\
\text { Hãy chỉ vào ngôn ngữ của quý vị. Một thông dịch viên sẽ được } \\
\text { gọi đến, quý vị sẽ không phải trả tiên cho thông dịch viên. }\end{array}$ \\
\hline
\end{tabular}


Figures

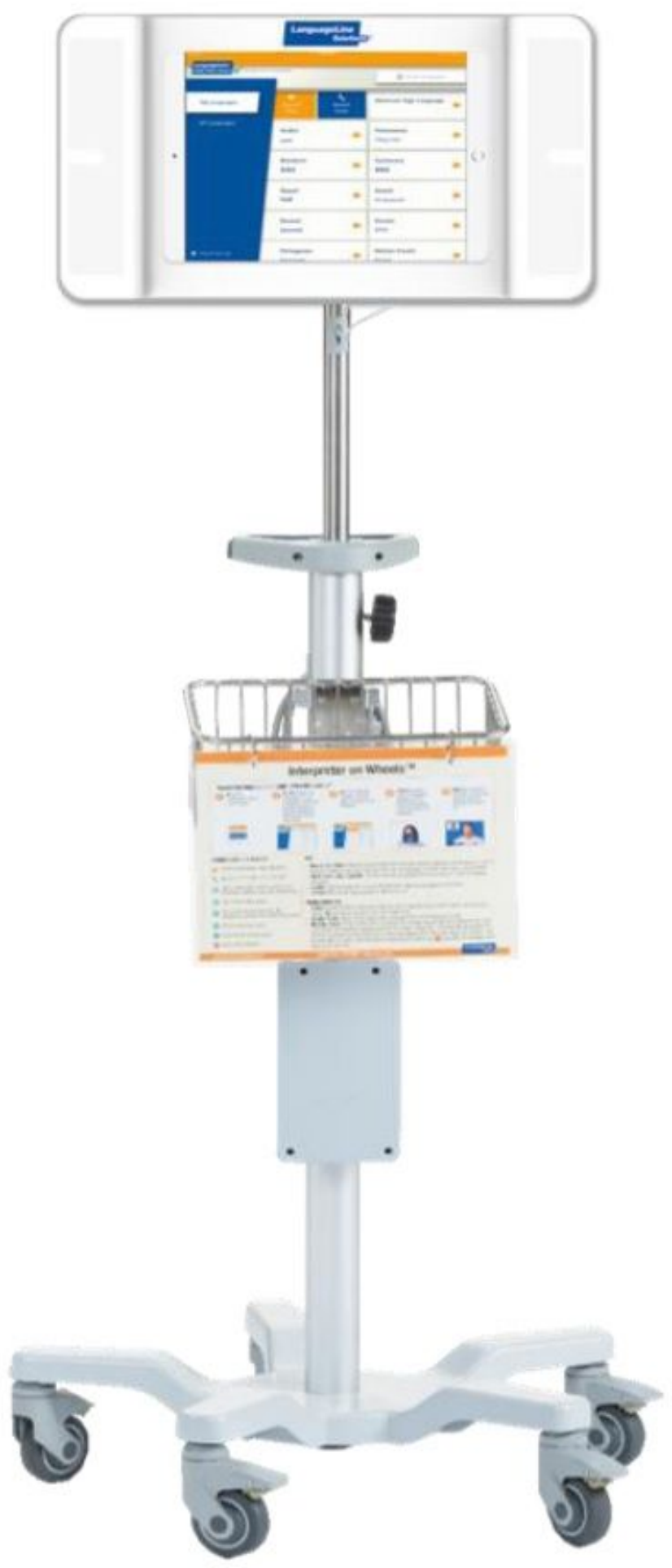

\section{Figure 1}

Interpreter on Wheels: it includes the digital MIS application displayed on the home screen of a tablet attached to an IV pole. 


\section{Language Interpretation Resources Comparison Guide}

AHS

PHONE

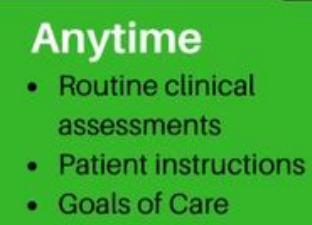

WHEN

to use

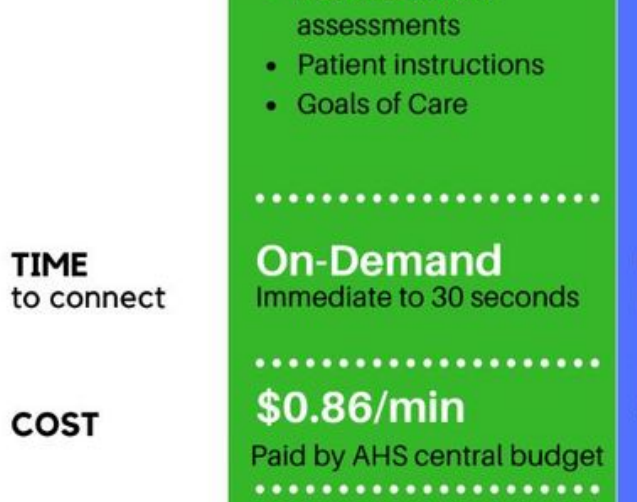

\section{LANGUAGES available}

\section{NO SHOW}

fees

HOW

to use

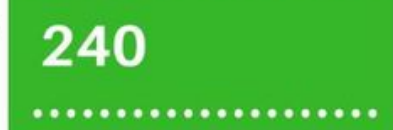

\section{None}

Dial in when needed

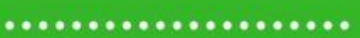

1. Dial 1-866-874-3972

2. Enter 6-digit client ID\#

3. Choose language

OR

1. Obtain AHS iPad or Video Interpreter on Wheels

2. Confirm Wi-Fi connection

3. Choose language

4. Click on Audio
For further information: Ellen Bruseker

Manager, Interpretation \&

Translation Services

(780) 719-6627

ellen.bruseker@ahs.ca
VIDEO

Anytime

- Routine \& Complex

clinical assessments

- Patient instructions

- Goals of Care

- Hearing impaired

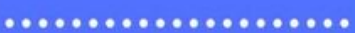

On-Demand

Immediate to 30 seconds

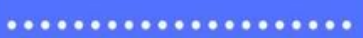

\section{$\$ 1.55 / \mathrm{min}$}

Paid by requesting unit

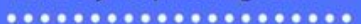

\section{0 \\ + American \\ Sign Language}

\section{None}

Dial in when needed

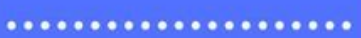

1.Obtain AHS iPad or Video Interpreter on Wheels

2. Confirm Wi-Fi connection

3. Choose language

4. Click on Video

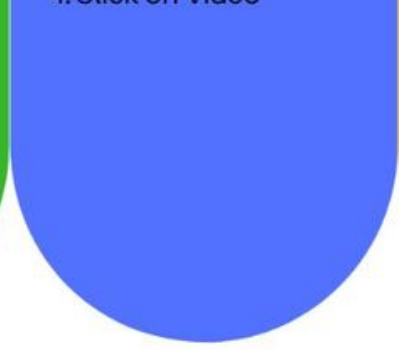

* American Sign Language paid by central AHS budget

\section{Complex}

- Lengthy family conferences

- Clinical assessments expected to last $>60$ minutes

\section{Schedule}

Advanced booking needed

\section{\$. 100/hr Flat Rate}

Paid by requesting unit

\section{0 \\ American}

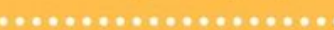

\section{$\$ 100 / \mathrm{hr}$}

Paid by requesting unit

1. Unit Manager or Triage Clerk calls In-Person Interpretation agency checks Interpreter availability

2. AHS Manager needs to sign off on request

3. Interpreter booked

Note: For any changes of cancellations, booking clerk needs to give 24 hours notice to the Interpreter

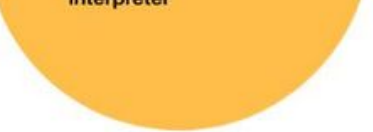

\section{Figure 2}

MIS usage poster showcasing the digital platforms, comprising of phone \& video modalities, compared to in-person interpretation 
Interpretation \&

Translation Services

\section{Interpreting Services Available}

English Translation: Point to your language. An interpreter will be called. The interpreter is provided at no cost to you.

\begin{tabular}{|c|c|}
\hline $\begin{array}{l}\text { American Sign Language } \\
\text { Point to your language. An interpreter will be called. } \\
\text { The interpreter is provided at no cost to you. }\end{array}$ & $\begin{array}{lr}\text { Oromo } & \text { Oromo } \\
\text { Gara afaan keetti eeri. Turjumaanni ni waamama. } & \\
\text { Turjumaanni beesee takka malee sif qophaawa. } & \end{array}$ \\
\hline 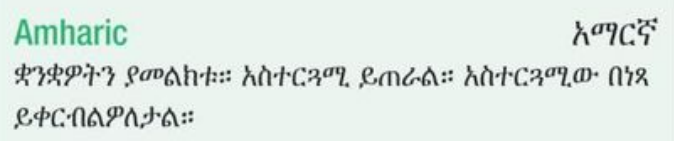 & 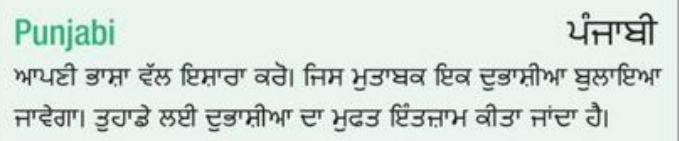 \\
\hline 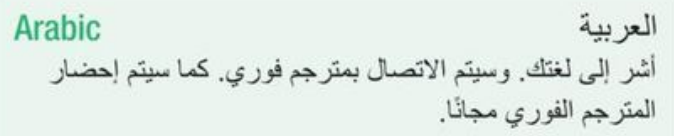 & $\begin{array}{l}\text { Russian Pусский } \\
\text { Укажите язык, на котором вы говорите. Вам вызовут } \\
\text { переводчика. Услуги переводчика предоставляются бесплатно. }\end{array}$ \\
\hline $\begin{array}{ll}\text { Cantonese } & \text { 廣東話 } \\
\text { 請指認您的語言, 以便為您提供免費 } & \\
\text { 的口譯服務。 } & \end{array}$ & $\begin{array}{l}\text { Somali Af-Soomaali } \\
\text { Farta ku fiiqluqadaada... Waxa laguugu yeeri doonaa turjubaan. } \\
\text { Turjubaanka wax lacagi kaaga bixi mayso. }\end{array}$ \\
\hline 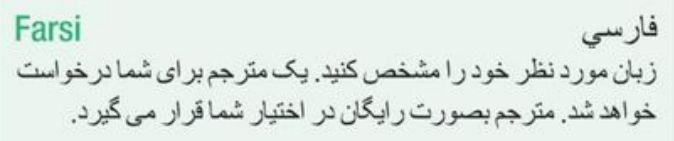 & $\begin{array}{l}\text { Spanish Español } \\
\text { Señale su idioma y llamaremos a un intérprete. El servicio } \\
\text { es gratuito. }\end{array}$ \\
\hline $\begin{array}{l}\text { French Français } \\
\text { Indiquez votre langue et nous appellerons un interprète. } \\
\text { Le service est gratuit. }\end{array}$ & $\begin{array}{l}\text { Swahili } \\
\text { Onyesha lugha yako. Mkalimani ataitwa. Utapewa } \\
\text { mkalimani bila gharama yoyote. }\end{array}$ \\
\hline $\begin{array}{l}\text { हिंदी } \\
\text { अपनी भाषा को इंगित करें। जिसके अनुसार आपके लिए दुभाषिया बुलाया } \\
\text { जाएगा। आपके लिए दुभाषिया की निशुल्क व्यवस्था की जाती है। }\end{array}$ & $\begin{array}{l}\text { Tagalog Tagalog } \\
\text { Ituro po ang inyong wika. Isang tagasalin ang ipagkakaloob } \\
\text { nang libre sa inyo. }\end{array}$ \\
\hline $\begin{array}{l}\text { Korean 한국어 } \\
\text { 귀하께서 사용하는 언어를 지정하시면 해당 언어 } \\
\text { 통역 서비스를 무료로 제공해 드립니다. }\end{array}$ & 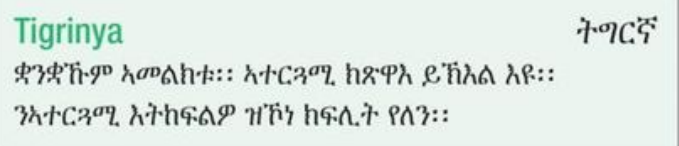 \\
\hline $\begin{array}{l}\text { Mandarin } \\
\text { 请指认您的语言, 以便为您提供免费 } \\
\text { 的口译服务。 }\end{array}$ & 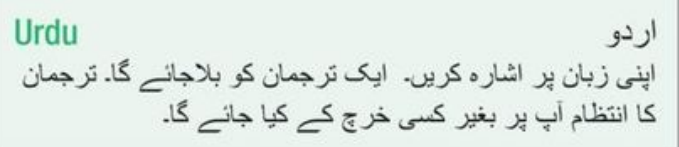 \\
\hline $\begin{array}{l}\text { नेपाली } \\
\text { आफ्नो भाषातर्फ औल्याउनुहोस्। एक दोभाषेलाई बोलाइनेछ। } \\
\text { तपाईंको कुनै खर्च बिना, एकजना दोभाषे उपलब्ध गराइनेछ। }\end{array}$ & $\begin{array}{l}\text { Vietnamese Tiếng Việt } \\
\text { Hãy chỉ vào ngôn ngữ của quý vị. Một thông dịch viên sẽ được } \\
\text { gọi đên, quý vị sẽ không phải trà tiền cho thông dịch viên. }\end{array}$ \\
\hline
\end{tabular}

\section{Figure 3}

Patient information poster showcasing top 20 languages in <Blinded $>$ with the same message - "Point to Your Language for Interpreters"

\section{Supplementary Files}


This is a list of supplementary files associated with this preprint. Click to download.

- CliniciansCapsule.docx

- EDStaffSurvey2020.pdf 